\section{JURNAL PENELITIAN PENDIDIKAN IPA}

http://jurnal.unram.ac.id/index.php/jpp-ipa
e-ISSN : 2407-795X

p-ISSN : 2460-2582

Vol 2, No, 1

Januari 2016

\title{
SKRINING FITOKIMIA DARI EKSTRAK BUAH BUNCIS (Phaseolus vulgaris L) DALAM SEDIAAN SERBUK
}

\author{
Rizki Nugrahani ${ }^{1}$, Yayuk Andayani ${ }^{2}$ dan Aliefman Hakim ${ }^{2}$ \\ Program Studi Magister Pendidikan IPA, Program Pascasarjana Universitas Mataram ${ }^{123}$ \\ Email: yayukkimia@gmail.com
}

\begin{abstract}
Key Words
Phytochemic

al screening,

bean fruit

extracts

Abstract

A research on the phytochemical screening of extracts of fruit powder beans (Phaseolus vulgaris $L$ ). The aims study was determine the content of chemical compound in extract beans that had undergone a process of heating at high temperature and has been stored in a specified time. Classified of chemical compounds would be included flavonoids, alkaloids, phenols, saponins, tannins, steroids and triterpenoids. Results of phytochemical screening showed bean extract contains the chemical compound class of flavonoids, alkaloids, phenols, saponins, steroids and triterpenoids.
\end{abstract}

\begin{tabular}{|c|c|}
\hline Kata Kunci & Abstrak \\
\hline $\begin{array}{l}\text { Skrining } \\
\text { fitokimia, } \\
\text { Ekstrak buah } \\
\text { buncis }\end{array}$ & $\begin{array}{l}\text { Telah dilakukan penelitian tentang skrining fitokimia dari serbuk ekstrak buah buncis } \\
\text { (Phaseolus vulgaris L). Penelitian ini bertujuan untuk mengetahui kandungan senyawa } \\
\text { kimia yang terdapat pada serbuk ekstrak buah buncis yang telah mengalami proses } \\
\text { pemanasan pada suhu tinggi dan telah disimpan dalam waktu yang sudah ditentukan. } \\
\text { Golongan senyawa kimia yang akan diuji meliputi flavonoid, alkaloid, fenol, saponin, } \\
\text { tanin, steroid dan triterpenoid. Hasil skrining fitokimia menunjukkan serbuk ekstrak } \\
\text { buah buncis mengandung senyawa kimia golongan flavonoid, alkaloid, fenol, saponin, } \\
\text { steroid dan triterpenoid }\end{array}$ \\
\hline
\end{tabular}




\section{PENDAHULUAN}

Tanaman buncis (Phaseolus vulgaris $\mathrm{L}$ ) atau yang lebih dikenal sebagai kacang buncis merupakan tanaman yang sangat mudah di temukan di seluruh wilayah Indonesia. Tanaman buncis berasal dari wilayah selatan Meksiko dan wilayah panas Guatemala.

Kandungan kimia tanaman buncis antara lain antosianin, flavonoid, alkaloid, saponin, triterpenoid, steroid, stigmasterin, trigonelin, arginin, asam amino, asparagin, kholina, tanin dan fasin (Sihombing dkk, 2010; Jannah dkk, 2013; Dzomba et al., 2013 dan Lima et al., 2014). Tanaman buncis dapat dimanfaatkan sebagai obat antara lain dapat menurunkan kadar gula darah (Jannah dkk, 2013) mencegah kanker usus besar dan kanker payudara (Waluyo dan Djuriah, 2013) serta dapat melancarkan pencernaan karena kandungan serat yang dimiliki (Batalla et al., 2006).

Kemampuan tanaman buncis menjadi tanaman obat tidak terlepas dari kemampuan meproduksi metabolit sekunder. Metabolit sekunder merupakan senyawa kimia yang umumnya memiliki kemampuan bioaktivitas dan berfungsi sebagai pertahanan terhadap gangguan hama dan penyakit untuk tumbuhan itu sendiri (Chunaifi dan Tukiran, 2014).

Berdasarkan hasil penelitian sebelumnya terhadap tanaman buncis dengan menggunakan ekstrak kental diketahui tanaman buncis mengandung komponen senyawa kimia seperti yang telah diuraikan diatas. Melengkapi informasi manaafat tanaman buncis di bidang fitofarmaka maka perlu dilakukan penelitian mengenai kandungan senyawa kimia tanaman buncis menggunakan ekstrak buah buncis yang sudah dikeringkan menggunakan proses pemanasan pada suhu tinggi dan penyimpanaan pada waktu yang sudah ditentukan.

\section{TUJUAN PENELITIAN}

Penelitian ini bertujuan untuk mengetahui kandungan senyawa metabolit sekunder yang terkandung dalam serbuk ekstrak buah buncis yang sudah mengalami proses pemanasan dan penyimpanan.

\section{LANDASAN TEORI}

Tanaman buncis merupak tanaman polong jenis semak atau perdu yang kaya akan manfaat. Terdapat dua tipe yaitu merambat dan tegak. Tanaman ini biasa dikonsumsi dalam keadaan muda atau dikonsumsi bijinya. Buncis dapat tumbuh liar, ditemukan pada daerah dataran rendah dan dataran tinggi pada lingkungan kering hingga lembab. Klasifikasi ilmiah tanaman buncis adalah sebagai berikut:

$\begin{array}{ll}\text { Kerajaan } & \text { : Plantae } \\ \text { Divisi } & \text { : Magnoliophyta } \\ \text { Kelas } & \text { : Magnoliopsida } \\ \text { Ordo } & \text { : Fabales } \\ \text { Famili } & \text { : Fabaceae } \\ \text { Upafamili } & \text { : Faboideae } \\ \text { Genus } & : \text { Phaseolus } \\ \text { Spesies } & : \text { P. Vulgaris Linn }\end{array}$

Tanaman buncis khususnya pada bagian buah memiliki manfaat besar karena kandungan gizi yang berlimpah. Hal tersebut merupakan gambaran dari kandungan kimia yang dimiliki oleh tanaman buncis. Kandungan kimia yang terdapat merupakan jenis senyawa polifenol yang umum terdapat pada tumbuhan seperti hasil penelitian yang dilakukan pada ekstrak kental tanaman buncis oleh Kurnia (2013) yaitu flavonoid yang dapat berfungsi sebagai antioksidan.

Senyawa polifenol merupakan metabolid sekunder terbesar pada tanaman (Ciptaningsih, 2012). Senyawa fenol terdiri dari sebuah cincin aromatik dengan satu atau lebih gugus hidroksil (Harbone, 2006). Senyawa fenol ada dalam bentuk stuktur sederhana hinga struktur kompleks yang rumit seperti tanin dan lignin. flavonoid (C6-C3-C6) tersusun atas 2 buah cincin fenil yang terikat melalui 3 atom karbon yang membentuk oksigenasi 
heterosiklik dari 3 cincin dengan label $\mathrm{A}$, B, C. srtuktur sederhana flavonoid disajikan pada Gambar 1 berikut:<smiles>O=c1c(O)c(-c2ccc(O)c(O)c2)oc2cc(O)ccc12</smiles>

Gambar 1. Stuktur Dasar Flavonoid

Beberapa ribu senyawa fenol alam telah diketahui strukturnya. Flavonoid merupakan golongan terbesar, tetapi fenol monosiklik sederhana, fenilpropanoid dan kuinon fenolik juga terdapat dalam julam besar. Golongan polimer penting seperti lignin, melamin dan tanin adalah senyawa polifenol dan terkadang satuan fenolik dijumpai pada protein , alkaloid dan diantara terpenoid (Harbone, 1987). Turunan senyawa fenol umumnya dapat digunakan dalam pengembangan obat tradisonal karena dapat berfungsi sebagai anti tumor, antiviral, antibiotik dan antioksidan (Apak et all., 2007).

\section{METODELOGI PENELITIAN}

Metode yang digunakan dalam penelitian ini adalah dengan mereaksikan serbuk sampel dengan reagen kimia yang sesuai dengan senyawa yang akan diidentifikasi. Bahan yang dibutuhkan dalam penelitian ini adalah serbuk ekstrak $P$ Vulgaris $L$ yang diperoleh dari industri obat tradisional di kota mataram, aquades, metanol $96 \%$ v/v, methanol $50 \%$ v/v, Serbuk magnesium, asam klorida pekat 37 $\%$ v/v, $\mathrm{H}_{2} \mathrm{SO}_{4}$ pekat $97 \%$ v/v, $\mathrm{FeCl} 31 \%$ w/v, $\mathrm{FeCl}_{3} 5 \%$ w/v, amoniak, klorofom, pereaksi dragendorff, pereaksi meyer, anhidra asetat, amil-alkohol. Alat yang akan dibutuhkan dalam penelitian ini adalah neraca analitik, pipet volumetri, cawan porselen, penangas air, waterbath, peralatan gelas, palate silika gel GF-254, fortex, chamber KLT, alat penyemprot, kertas saring, dan alumunium foil. Penelitan dilakukan di Laboratorium Analitik Universitas Mataram.

Prosedur penelitian terdiri dari beberapa tahapan yaitu tahap penyiapan sampel dimana sampel diambil dari industri obat tradisional yang terdapat di kota mataram dalam bentuk serbuk ekstrak.

Tahap selanjutnya adalah tahap skrining fitokimia. Skrining fitokimia yang dilakukan meliputi uji flavonoid, alkaloid, fenol, saponin, tanin, steroid dan triterpenoid, metode analisis berdasarkan (Harborne, 1987 dalam Nugrahani, 2015)

\section{a. flavonoid.}

Sebanyak 0,1 ekstrak dimasukan kedalam gelas piala kemudian kemudin ditambahkan $10 \mathrm{ml}$ aquades dipanaskan sampai mendidih selama 5 menit. Setelah itu, disaring dan filtratnya digunakan sebagai larutan uji. Filtrat dimasukkan ke dalam tabung reaksi lalu ditambahkan pita $\mathrm{Mg}, 1 \mathrm{ml} \mathrm{HCl}$ pekat dan $1 \mathrm{ml}$ amilalkohol kemudian dikocok dengan kuat. Uji positif flavonoid ditandai dengan terbentuknya warna merah, kuning atau jingga pada lapisan amilalkohol.

b. Alkaloid.

Sebanyak $0,1 \quad$ gr $\quad$ sampel dilarutkan dalam $10 \mathrm{ml} \quad \mathrm{CHCl}_{3}$ (kloroform) dan 4 tetes $\mathrm{NH}_{4} \mathrm{OH}$ kemudian disaring dan filtratnya dimasukkan kedalam tabung reaksi tertutup. Ekstrak $\mathrm{CHCl}_{3}$ dalam tabung reaksi kemudian dikocok dengan ditambah 10 tetes $\mathrm{H}_{2} \mathrm{SO}_{4} 2 \mathrm{M}$, sampai terbentuk 2 lapisan. Lapisan asam yang berada di atas dipisahkan ke dalam tabung reaksi yang lain dan ditambahkan preaksi meyer yang menghasilkan endapan warna putih sedangkan penambahan pereaksi dragendorff yang akan menimbulkan endapan warna merah jingga.

\section{c. Fenol}

Sejumlah sampel $(0,1 \quad$ gr $)$ diekstrak dengan $20 \mathrm{ml}$ metanol $70 \%$. 
Larutan yang dihasilkan diambil sebanyak $1 \mathrm{ml}$ kemudian ditambahkan 2 tetes larutan $\mathrm{FeCl}_{3} 5 \%$. Reaksi positif ditunjukkan dengan terbentuknya warna hijau atau hijau kebiruan.

\section{d. Saponin}

Sebanyak $0,1 \quad$ gr sampel dimasukkan kedalam gelas piala kemudian ditambahkan $10 \mathrm{ml}$ air panas dan dididihkan selama 5 menit. Setelah itu, disaring dan filtratnya digunakan sebagai larutan uji. Filtrat dimasukkan kedalam tabung reaksi tertutup kemudian dikicok selama \pm 10 detik dan dibiarkan selama 10 menit, ditambahkan $1 \mathrm{ml}$ HCL 2M. Adanya saponin ditunjukkan dengan terbentuknya buih yang stabil.

\section{e. Tanin}

Sebanyak 0,1 gr serbuk ekstrak ditambahkan dengan $10 \mathrm{ml}$ air panas, dididihkan selama 5 menit dan disaring. Sebagian filtrat yang diperoleh ditambahakan dengan larutan $\mathrm{FeCl}_{3} 1 \%$. Hasil positif ditunjukkan oleh terbentuknya warna hijau kehitaman.

\section{f. Triterpenoid dan Steroid.}

Sebanyak 0,1 gr sampel dilarutkan dengan metanol kemudian di uapkan diatas waterbath. Filtrat digerus kemudian dilarutkan dengan 2 $\mathrm{ml}$ kloroform dalam tabung reaksi, lalu ditambah dengan anhidra asetat sebanyak 10 tetes, selanjutnya larutan ditetesi dengan $\mathrm{H}_{2} \mathrm{SO}_{4}$ pekat \pm 3 tetes melalui dinding tabung reaksi. Jika hasil yang diperoleh berupa cicin kecoklatan atau violet pada perbatasan dua pelarut menunjukkan adanya triterpen, sedangkan munculnya warna hijau menunjukkan adanya steroid.

\section{HASIL DAN PEMBAHASAN}

Sampel serbuk diperoleh dari industri obat di kota mataram. Sampel di produksi dengan metode perendaman buah buncis segar menggunakan pelarut air dan dikeringkan dengan cara pemanasan pada suhu tinggi setelah menjadi serbuk sampel diletakkan dalam botol plastik tertutup kemudian disimpan dalam variasi waktu yang sudah ditentukan yaitu kurang dari 1 bulan s/d \pm 3 bulan pada suhu ruang.

Analisis fitokimia serbuk ekstrak buncis yang dilakukan antara lain identifikasi tanin, saponin, alkaloid, fenol, flavonoid dan Streroid/Triterpenoid. Hasil analisis fitokimia menggunakan pereaksipereaksi kimia, diuraikan sebgai berikut:

\section{a. Flavonoid}

Hasil uji flavonoid untuk masing-masing sampel dinyatakan positif, karena pengujian serbuk ekstrak menggunakan $\mathrm{HCl}$ pekat dan potongan pita magnesium menghasilkan warna oranga/ jingga pada lapisan amil alkohol. Hasil uji ditunjukkan pada Gambar 2.

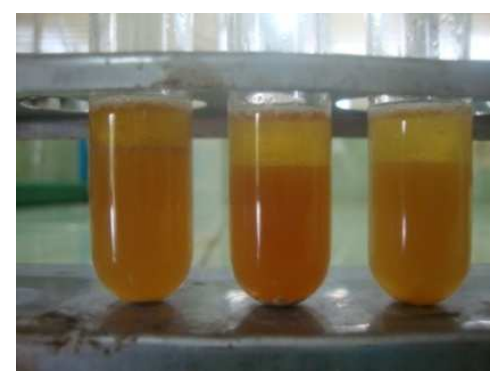

Gambar 2. Hasil uji Flavonoid (Nugrahani, 2015)

Reaksi yang terjadi pada saat uji flavonoid dapat di jelaskan pada Gambar 3.

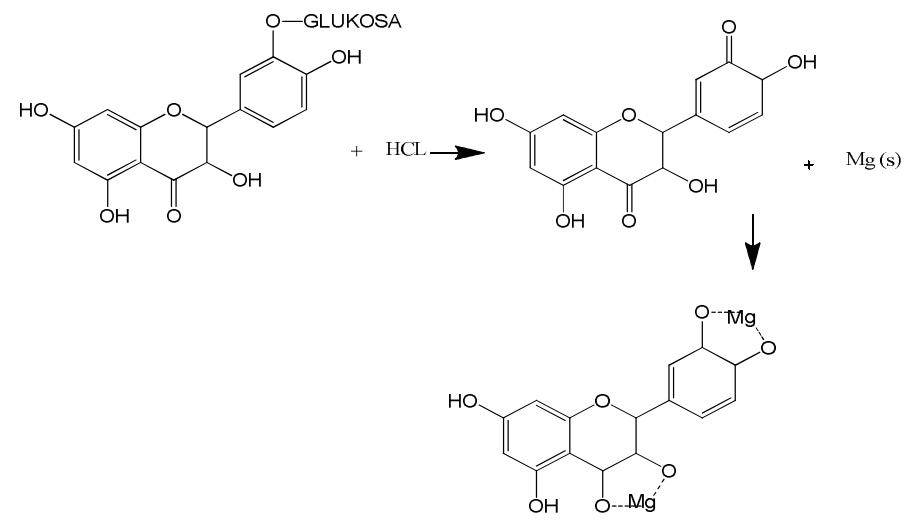

Gambar 3. Reaksi flavonoid dengan $\mathrm{HCl}$ dan logam Magnesium 


\section{b. Alkaloid}

Sampel Serbuk ekstrak buncis dengan variasi penyimpanan yang berbeda menunjukkan semua sampel mengandung senyawa alkaloid, karena saat di tetesi dengan reagen Dragendorf dan reagen Meyer mengahasilkan endapan berwarna jingga kemerahan untuk reagen Dragendorf dan endapat berwarna putih untuk reagen Meyer (Gambar 4)

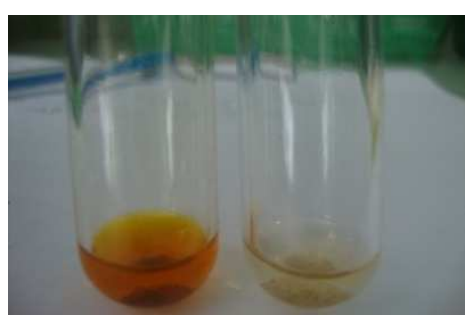

Gambar 4. Hasil Uji Alkaloid (Nugrahani, 2015)

Endapan yang terbentuk merupakan kalium-alkaloid, karena senyawa alkaloid mengandung atom nitrogen yang mempunyai pasangan elektron bebas sehingga dapat digunakan untuk membentuk ikatan kovalen koordinat dengan ion logam. Nitrogen pada alkaloid akan bereaksi dengan ion logam $\mathrm{K}+\quad$ dari kalium tetraiodomerkurat(II) membentuk kompleks kalium-alkaloid yang mengendap (Marliana, 2005) reaksi yang terjadi dengan pereaksi Meyer ditunjukkan pada Gambar 5.

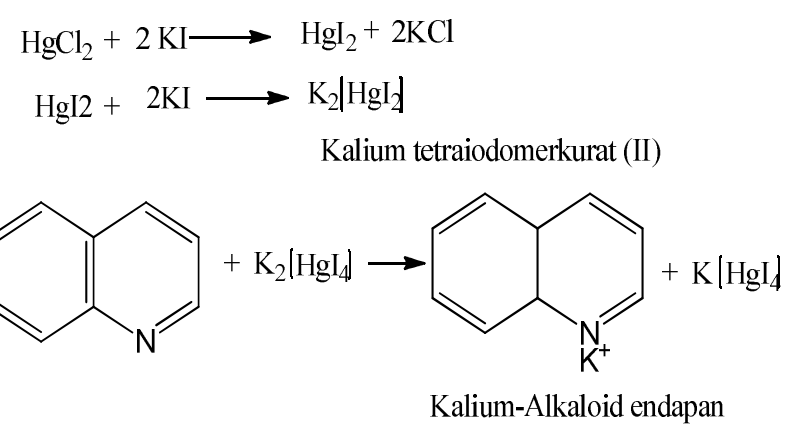

Gambar 5. Reaksi dengan pereaksi Meyer

Hasil positif alkaloid pada uji Dragendorff juga ditandai dengan terbentuknya endapan coklat muda sampai kuning jingga. Endapan tersebut adalah kaliumalkaloid. Nitrogen pada uji alkaloid dengan pereaksi Dragendorff digunakan untuk membentuk ikatan kovalen koordinat dengan $\mathrm{K}+$ yang merupakan ion logam (Marliana, 2005). Reaksi pada uji Dragendorff ditunjukkan pada Gambar 6.

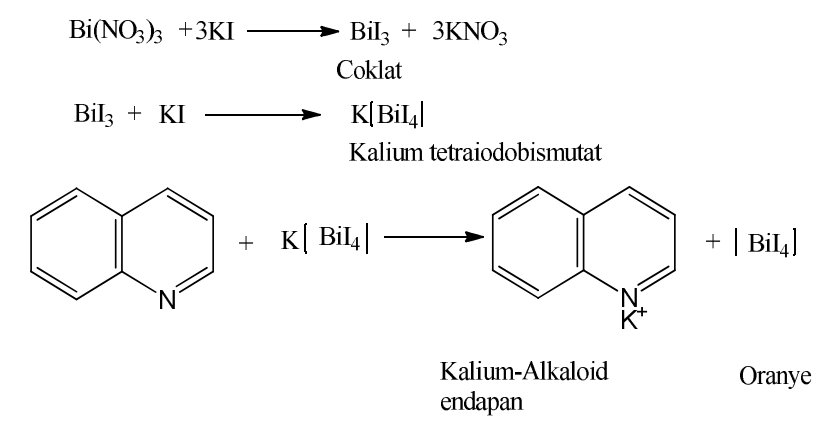

Gambar 6. Reaksi dengan pereaksi dragendorf

\section{c. Fenol}
Sampel serbuk ekstrak buncis positif mengandung senyawa fenol karena memberikan perubahan warna hijau kekuningan. Hasil uji ditunjukkan pada Gambar 7.

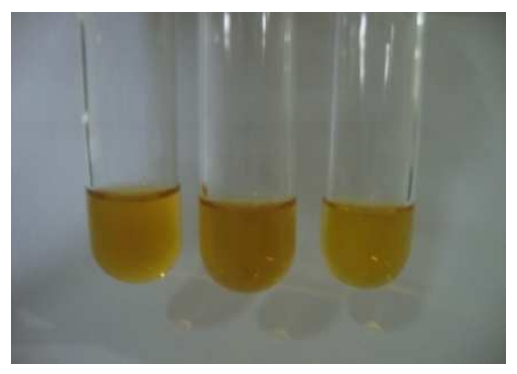

Gambar 7. Hasil uji Fenol (Nugrahani, 2015)

Reaksi yang terjadi dinyatakan sebagai berikut:

$\mathrm{FeCl}_{3(\mathrm{aq})}+6 \mathrm{ArOH}_{(\mathrm{s})} \rightarrow 6 \mathrm{H}^{+}+3 \mathrm{Cl}-+[\mathrm{Fe}(\mathrm{Oar}) 6]^{3-}{ }_{(\mathrm{aq})}$

\section{d. Saponin}

Pengujian senyawa saponin dilakukan dengan memanaskan sampel yang ditambahkan dengan air hingga mendidih selama 5 menit, setelah dingin sampel di kocok dengan kuat sehingga terbentuk busa kemudian ditambahkan $\mathrm{HCl} 2 \mathrm{M}$. Hasil yang diperoleh menunjukkan bahwa 
sampel serbuk ektrak buncis mengandung saponin karena terbentuk busa yang stabil selama 10 menit (Gambar 8).

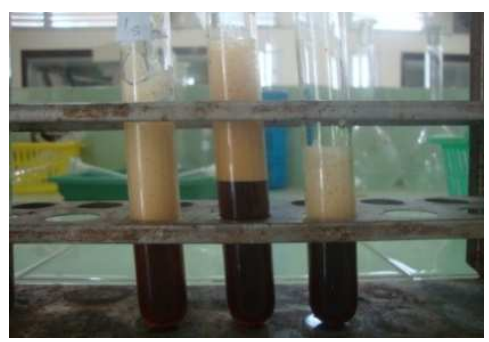

Gambar 8. Hasil Uji Saponin (Nugrahani, 2015)

Timbulnya buih menunjukkan adanya glikosida yang mempunyai kemampuan membentuk buih dalam air yang terhidrolisis menjadi glukosa dan senyawa lainnya. Rekasi yang terjadi saat uji saponin ditunjukkan pada Gambar 9.

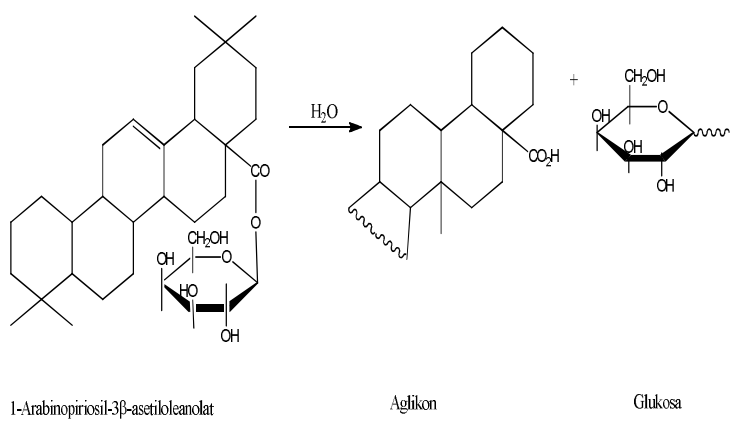

Gambar 9. Reaksi Hidrolisis Saponin dalam Air

\section{e. Tanin}

Pengujian senyawa tanin menunjukkan hasil negatif karena tidak terjadi prubahan warna hijau kehitaman pada saat penambahan $\mathrm{FeCl}_{3} 1 \%$ (Gambar 10).

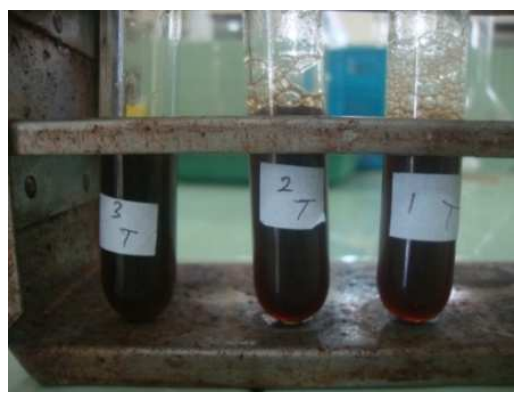

Gambar 10. Hasil Uji Tanin (Nugrahani, 2015)

\section{f. Steroid dan Triterpenoid}

Masing-masing sampel dinyatakan positif mengandung senyawa steroid dan triterpenoid, karena setelah sampel ditambahkan larutan anhidrida asetat dan asam sulfat pekat menghasilkan cincin kecoklatan pada perbatasan dua pelarut, adanya perubahan warna menjadi hijau pada larutan menunjukkan adanya senyawa steroid (Gambar 11).

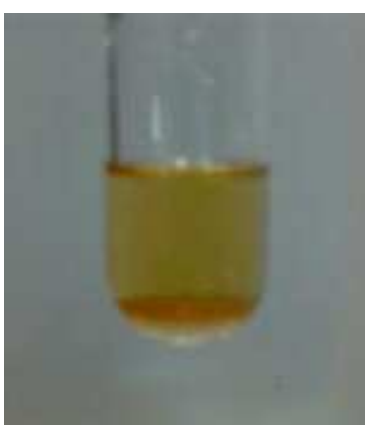

Gambar 11. Hasil uji Steroid dan Triterpenoid (Nugrahani, 2015)

Prinsip reaksi dalam mekanisme reaksi uji triterpenoid yang disajikan dalam Gambar 11 merupakan kondensasi atau pelepasan $\mathrm{H}_{2} \mathrm{O}$ dan penggabungan dengan karbokation. Reaksi ini diawali dengan proses asetilasi gugus hidroksil menggunakan asam asetat anhidrida. Gugus asetil yang merupakan gugus pergi yang baik akan lepas, sehingga terbentuk ikatan rangkap.Selanjutnya terjadi pelepasan gugus hidrogen beserta elektronnya, mengakibatkan ikatan rangkap berpindah. Senyawa ini mengalami resonansi yang bertindak sebagai elektrofil atau karbokation. Serangan karbokation menyebabkan adisi elektrofilik, diikuti pelepasan hidrogen. Kemudian gugus hidrogen beserta elektronnya dilepas, akibatnya senyawa mengalami perpanjangan konjugasi yang memperlihatkan munculnya cincin kecoklatan ( Setyowati dkk, 2014). 


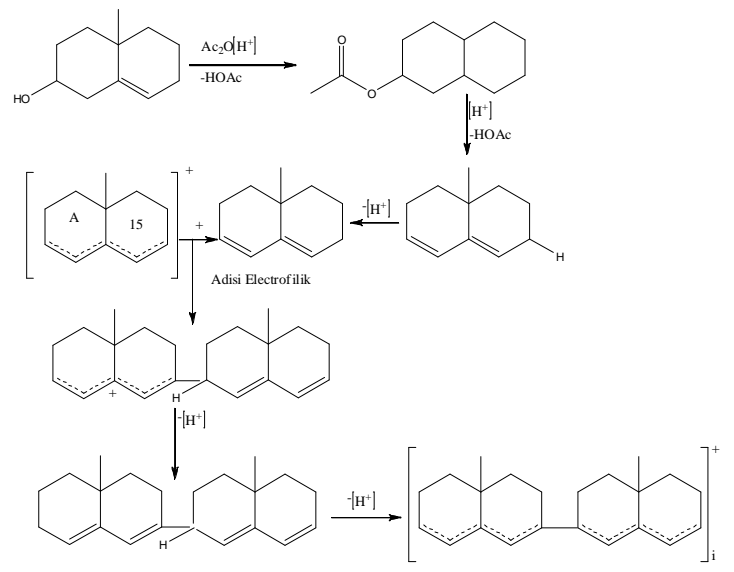

Gambar 12. Reaksi triterpenoid dengan pereaksi Liembermann-Burchard
Berdasarkan hasil uji fitikomia menunjukkan bahwa sampel serbuk ekstrak buncis dengan variasi lama penyimpanan yang berbeda yaitu sampel segar (kurang dari 1 bulan), sampel yang di simpan \pm 1 bulan, sampel yang disimpan \pm 2 bulan dan sampel yang disimpan \pm 3 bulan mengandung senyawa kimia golongan saponin, fenol, flavonoid dan alkaloid, sedangkan senyawa tanin tidak terdapat pada semua sampel. Ringkasan hasil uji fitokimia disajikan pada Tabel 4.4 .

Tabel 4.4 Hasil Uji Fitokimia

\begin{tabular}{|c|c|c|c|c|c|c|}
\hline \multirow{2}{*}{$\begin{array}{l}\text { Jenis } \\
\text { sampel }\end{array}$} & \multicolumn{6}{|c|}{ Golongan Senyawa } \\
\hline & Tanin & Saponin & Fenol & Flavonoid & Alkaloid & $\begin{array}{l}\text { Steroid/ } \\
\text { Triterpenoid }\end{array}$ \\
\hline$<1$ Bulan & - & + & + & + & + & $+/+$ \\
\hline 1 bulan & - & ++ & + & + & + & $+/+$ \\
\hline 2 bulan & - & ++ & + & + & + & $+/+$ \\
\hline 3 bulan & - & ++ & + & + & + & $+/+$ \\
\hline
\end{tabular}

\section{KESIMPULAN}

Serbuk ekstrak buah buncis yang telah mengalami pemanasan pada suhu tinggi dan telah disimpan selama kurang dari $1 \mathrm{~s} / \mathrm{d} \pm 3$ bulan masih mengandung komponen senyawa poliphenol seperti saponin, fenol, alkaloid, flavonoid dan triterpenoid.

\section{DAFTAR PUSTAKA}

Akbar, H. R. 2010. Isolasi dan Identifikasi Golongan Flavonoid Daun Dandang Gendis (Clinachanthus nutans)Berpotensi Sebagai Antioksidan. Institut Pertanian Bogor.

(Online, http://repository.ipb.ac.id/handle/1 23456789/26741).

Apak, R., Guclu, K., Demirata, B., Ozyurek, M., Celik, S.E.,
Bektasoglu, B., Berker, $\mathrm{K}$ and Ozyurt, D. 2007. Comparative Evaluation of Various Total Antioxidant Capacity Assays Applied to Phenolic Compounds with the CUPRAC Assay. Molecules, 12: 1496-1547.

(Online,

http://www.ncbi.nlm.nih.gov/pubm ed/17909504)

Balafif., Andayani., Gunawan. 2013. Analisis Senyawa Triterpenoid dari hasil Fraksinasi Ekstrak Air Buncis (Phaseolus vulgaris Linn). Tesis S2. Magister Pendidikan IPA. Universitas Mataram.

Batalla., Widholm., fahey., Tostado., Lopez. $2006 . \quad$ Chemical Components with Health Implications in Wild and Cultivated Mexican Common Bean Seeds (Phaseolus vulgaris L.). 
Jurnal Agricultural And Food Chemistry. 54: 2045-2052.

Dzomba, P., Togarepi, E., Mupa, M. 2013. Anthocyanin Content and Antioxidant Activities of Commmon Bean Species (Phaseolus vulgaris L.) Grown In Mashonaland Central, Zimbabwe. African Journal of Agricultural Research.

(Online,http://www.academicjourn als.org/journal/AJAR/articleabstrac t/F4BC4AF36155).

Harbone. 1987. Metode Fitokimia Penuntun Cara Modern Menganalisi Tumbuhan. Kosasih Padmawinata, Iwang Soediro (penerjemah). Bandung. ITB.

Jannah., Sudarma., Andayani. 2013. Analisis Senyawa Fitosterol Dalam Ekstrak buah Buncis (Phaseolus vulgaris L.). Program Pascasarjana, Universitas Mataram.

Kurnia, N. 2013. Uji Aktivitas Antioksidan Ekstrak Air Buah Buncis (Pheseolus vulgaria L.). Tesis S2. Universitas Mataram.

Lima, P. F. d., Colombo, C. A., Chiorato, A.F., Yamaguchi, L. F., Kato, M. J and Carbonell, S. A. M. 2014. Occurrence of Isoflavonoids in Brazilian Common Bean Germplasm (Phaseolus vulgaris L.). Jurnal Agricultural and Food Chemistry. 62:9699-9704

Marliana, S. D., Suryanti,V dan Suyono. 2005. Skrining Fitokimia dan
Analisis Kromatografi Lapis Tipis Komponen Kimia Buah Labu Siam (Sechium edule Jacq. Swartz.) dalam Ekstrak Etanol. Biofarmasi. 3(1):26-31.

Nugrahani, R. 2015. Analisis Potensi Serbuk Ekstrak Buncis (Phaseolus vulgaris L.) sebagai Antioksidan. Tesis S2. Universitas Mataram.

Sihombing, Noventy C. 2010. Formula Gel Antioksidan Ekstrak Buah Buncis (Phaseulus vulgaris L) dengan Menggunakan Basis AQUPEC 505 HV. Jurnal ilmiah universitas padjadjaran.

Waluyo, N., Djuariah, D. 2013. VarietasVarietas Buncis ( Pheseolus vulgaris L.) yang telah Dilepas oleh Balai Penelitian Tanaman Sayur. Balai Penelitian Tanaman Sayur. Bandung.

Wikipedia.http://id.wikipedia.org/wiki/Bu ncis, diakses tanggal 26 November 2014.

Ciptaningsih, E. 2012. Uji Aktivitas Antioksidan dan Karakteristik Fitokimia pda Kopi Luwak Arabika dan Pengaruhnya terhadap Tekanan Darah Tikus Normal dan Tikus Hipertensi. Tesis S2. Universitas Indonesia.

Chunaifi, M dan Tukiran. 2014. Skrining Fitokimia dari Ekstrak Etil Asetat Kulit Batang Tumbuhan Nyiri Batu (Xylocarpus moluccencis). UNESA Journal of Chemistry. 